\title{
Optimization model for the installation of SAMU bases: application in Natal-RN
}

Eric Lucas dos Santos Cabral ${ }^{1}$, Federal University of Rio Grande do Norte, Brazil Wilkson Ricardo Silva Castro ${ }^{2}$, Federal University of Rio Grande do Norte, Brazil Claudia Aparecida Cavalheiro Francisco ${ }^{3}$, Federal University of Rio Grande do Norte, Brazil Ricardo Pires de Souza ${ }^{4}$, Federal University of Rio Grande do Norte, Brazil

\section{RESUMO}

Objetivo - O objetivo deste estudo foi a aplicação de um modelo matemático com o objetivo de designar bairros para instalação de novas bases do Serviço de Atendimento Móvel de Urgência (SAMU) que minimizem a distância percorrida pelas ambulâncias na cidade de Natal / RN.

Metodologia - Os dados foram agrupados para obtenção de parâmetros como: distrito de atendimento, horário, dia da semana, número de acidentes. Após a coleta e processamento dos dados, foi criada uma matriz de distância bairro a bairro na cidade de Natal com base no Google Maps. Um modelo baseado no algoritmo p-medianas foi criado para minimizar a distância percorrida por ambulâncias com o auxílio do programa AIMMS.

Resultados - A aplicação do modelo permitiu a simulação de cenários com a instalação de 3 a 8 bases fixas. Houve uma redução significativa na distância percorrida pelas ambulâncias que chegou a 48\%, após a instalação de oito bases. Ou seja, houve redução de 6.560 quilômetros percorridos por mês por ambulâncias.

Implicações de pesquisa, práticas e sociais - A redução da distância total percorrida pelas ambulâncias tem implicações práticas e sociais, uma vez que proporciona um aumento do número de ambulâncias disponíveis para servir a população e reflete diretamente na redução do tempo médio de resposta de o serviço.

Contribuições - $\mathrm{O}$ artigo contribui para o debate sobre a eficiência dos serviços de emergência médica brasileiros ao propor soluções de engenharia e gestão para o monitoramento de indicadores críticos, como o tempo de resposta.

Palavras-chave - Serviço de emergência médica. Cuidados de saúde. Modelo de simulação.

\section{ABSTRACT}

Purpose - The objective of this study was the application of a mathematical model aiming to designate neighborhoods for the installation of new Mobile Emergency Care Service (SAMU) bases that minimize the distance traveled by the ambulances in the city of Natal / RN.

Design/methodology/approach -The data were grouped in order to obtain parameters, such as: call district, time, day of the week, number of accidents. After data collection and processing, a matrix of neighborhood-to-neighborhood distance in the city of Natal based on Google Maps was created. A model was created to minimize the distance traveled by ambulances with the aid of the AIMMS program.

Findings - The application of the model allowed for the simulation of scenarios with the installation of 3 to 8 fixed bases. There was a significant reduction in the distance traveled by the ambulances which reached $48 \%$, after the installation of eight bases. In other words, there was a reduction of 6,560 kilometers traveled per month by ambulances. Research, Practical \& Social implications - The reduction in the total distance covered by the ambulances has practical and social implications, since it provides an increase in the number of ambulances available to serve the population and directly reflects in the reduction in the average response time of the service.

Originality/value - The article contributes to the debate on efficiency in Brazilian medical emergency services by proposing engineering and management solutions for monitoring critical indicators such as response time.

Keywords - Emergency medical service. Health care. Model simulation

1. Avenida Senador Salgado Filho, 3000 Centro de Convivência Djalma Marinho Sala 09 S/N - Lagoa Nova, Natal - RN, ericlucascabra194@gmail.com, https://orcid.org/0000-0003-2855-7049; 2 wilkson.rsc@ gmail.com, https://orcid.org/0000-0002-74933802; 3. 3claudiacavalheirof@gmail.com, https://orcid.org/0000-0001-7873-0933; 4. ripiso@ gmail.com, https://orcid.org/0000-00022922-0985.

CABRAL, E.L.S.; CASTRO, W.R.S.; FRANCISCO, C.A.C.; SOUZA, R.P. Optimization model for the installation of Samu bases. application in Natal-RN. GEPROS. Gestão da Produção, Operações e Sistemas, v. 15, n. 4, p. 205 - 218, 2020.

DOI: http://dx.doi.org/10.15675/gepros.v15i4.2668 


\section{INTRODUCTION}

The need to provide urgent and emergency care services to the population is a concern of city governance, since access to health is one of the fundamental factors for people's wellbeing (MALTA et al., 2016), especially the which are positioned in urban areas. In these locations there are significant number of traffic accidents and other serious occurrences such as heart attack, drowning, firearm drilling and disasters (floods, landslides, earthquakes, for example).

In Brazil and other Latin American countries most deaths are caused by urban violence and vehicle traffic (PAHO, 2009; REICHENHEIM et al., 2011). Figures endorsing this assertion show that in Brazil in 2014, according to the Ministry of Health (2014) and FLACSO (2014), there were 43,075 traffic-related deaths and 44,861 homicides with fatalities.

In this context, the Emergency Medical Service is responsible for providing acute prehospital care for patients with diseases and injuries and has the fundamental role of providing quality services to people (ARINGHIERI; CARELLO; MORALE, 2016) minimizing the degree of injuries and even the number of deaths.

The Mobile Emergency Care Service (SAMU) is an example of emergency medical service institutions in Brazil. The purpose of SAMU is to reach the victim early after an injury of various kinds to their health that may lead to suffering, sequelae or even death by sending manned vehicles by trained staff (MINISTRY OF HEALTH, 2012). The location of ambulance bases is an important factor in relation to the potential requesters of this service (KIM; LEE, 2015) for the fast service time fulfillment.

As an example of these occurrences, there is generally a need for a satisfactory response time so that the lives of potential users of this service are not at risk. Some restrictions associated with proper response time performance by the emergency medical service are: traffic conditions, weather conditions, days of the week (INGOLFSSON et al, 2007) and even hospital conditions, as there may be retention of stretchers in these spaces and, therefore, retention of ambulances: a scenario that influences the quality of the emergency medical service.

The average response time is a variable that needs to be minimized, as its maximization may lead to the deterioration of the service user's health and lead to death. 
Some cataloged examples of cities with more than one million inhabitants in Brazil and around the world explain the average response time for extremely urgent care: in the UK it should be at most 8 minutes on $75 \%$ of calls and 19 minutes for serious calls but not urgent (WANKHADE, 2011; FRAZÃO et al., 2018). In Vienna, Austria, the average response time recorded in 2015 was 15 minutes considering a 10\% dispersion of this figure upwards or downwards due to heavy vehicle traffic restrictions and weather conditions. In Brazil, in Belo Horizonte, the average response time in 2010 was approximately 21 minutes (NOGUEIRA JUNIOR, 2011). In Campinas, interior of the State of Sao Paulo, the average response time was 12 minutes in 2004 (TAKEDA; WIDMER; MORABITO, 2007; CABRAL et al., 2018).

Based on the discussion above, is it possible to develop a mathematical model that shows the most appropriate positioning for the SAMU bases so that there is a significant decrease in the emergency response time?

In order to answer this question, this article will present the necessary structure for the development of a mathematical model that will allow the exact positioning of the SAMU bases to be defined in order to decrease the average response time of emergency units in relation to occurrences. The geographic location chosen for this research was Natal, capital of the state of Rio Grande do Norte, Brazil.

\section{METHODOLOGICAL PROCEDURES}

The first phase of the work consisted of a descriptive statistical study aiming at understanding the data from the SAMU system. The data were grouped in order to obtain parameters, such as: call district, time, day of the week, number of accidents.

After data collection and processing, a matrix of neighborhood-to-neighborhood distance in the city of Natal based on Google Maps was created. This matrix aimed to verify the total distance of ambulance displacement in the calls, considering only the distance from the base of origin exit to the neighborhood of the accident round trip. To simplify the model at this time, it was not considered in this modeling the displacement of the called neighborhood to the hospitals.

For some conclusions it is necessary to know the number of inhabitants per neighborhood of the municipality of Natal. These data were collected on the IBGE website and considered the 2010 census. 
After processing the call data, a model was created to minimize the distance traveled by ambulances with the aid of the AIMMS program. Several scenarios with different number of bases were created in the model and then compared with the current scenario in 2015 for fixed bases.

\section{RESULTS AND DISCUSSION}

In 2015 , the total number of calls per zone was 19,588 , therefore, an average of approximately 1,632 calls answered per month, in Natal, capital of the state of Rio Grande do Norte, as shown in Figure 1 below:

Figure 1 - Calls and population in the city of Natal / RN

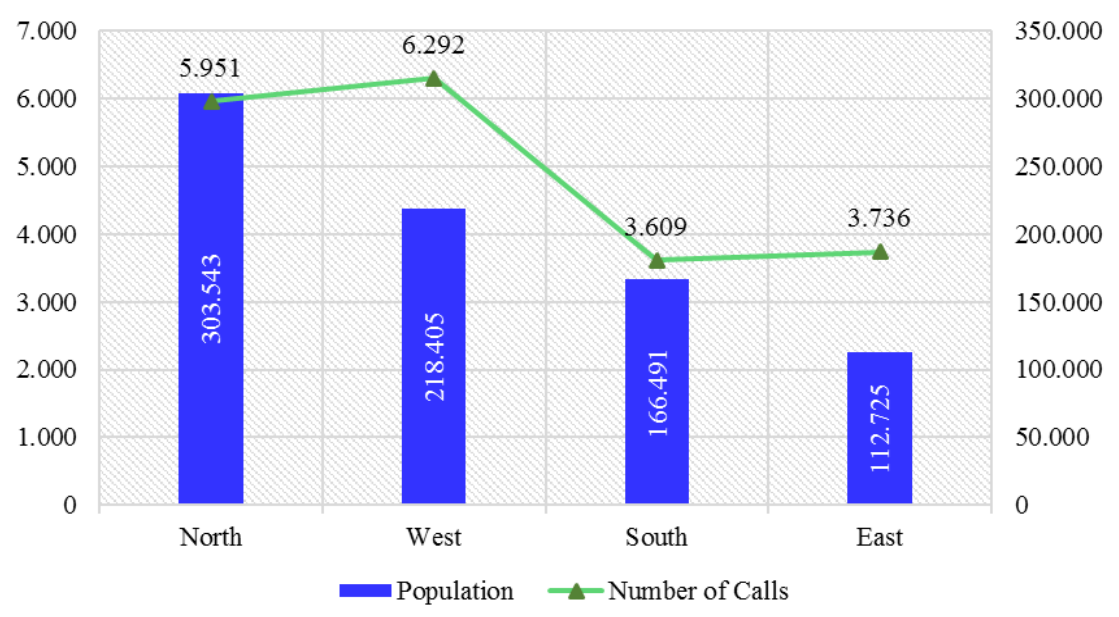

Source: the authors.

It was also verified that the total of attendances in 2015, with ambulance referral to the demanded location, was 23,165 , therefore, an average of approximately 1,930 calls per month in Natal, capital of the state of Rio Grande do Norte, as shown in Figure 2: 
Figure 2 - Monthly attendance in the city of Natal / RN

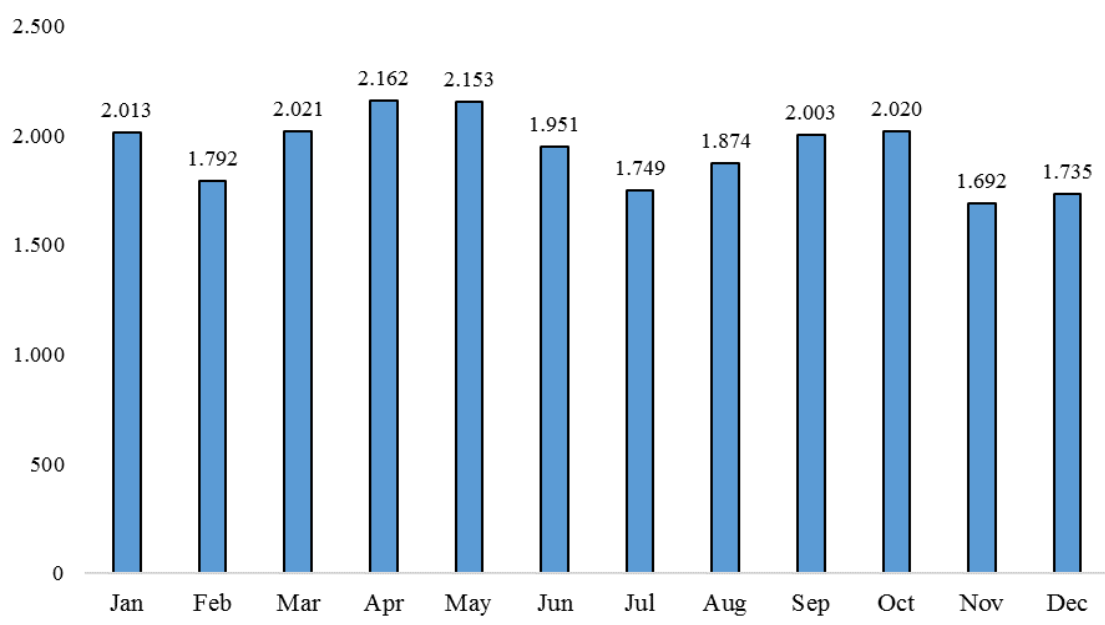

Source: the authors.

Figure 3 illustrates the number of calls per day of the week in the year 2015. It was identified based on the Figureical analysis that $45 \%$ of the total calls are concentrated on Fridays, Saturdays and Sundays. This year, Saturday was the day of the week with the highest concentration of calls.

Figure 3 - Calls by day of the week in the city of Natal / RN

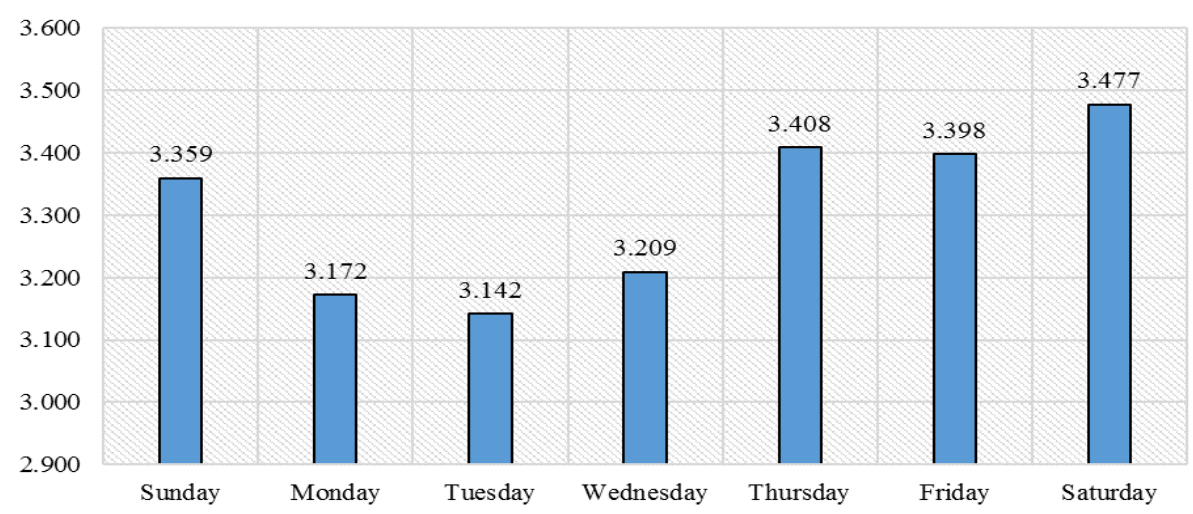

Source: the authors.

In 2015, SAMU Natal had an infrastructure with three fixed bases, located in the neighborhoods of Dix-Sept Rosado (Central), Cidade da Esperança (UPA) and Nossa Senhora da Apresentação (Maternity Leide Moraes). The average response time of each of the fixed bases in 2015 is shown in Figure 4. To compose this average response time we considered only the calls with red attendance code (urgency), since in this type of call it is necessary that 
the displacement to the plaintiff be as fast as possible, which assumes that the response time will be as short as possible.

Figure 4 - Average response time by SAMU Natal / RN base

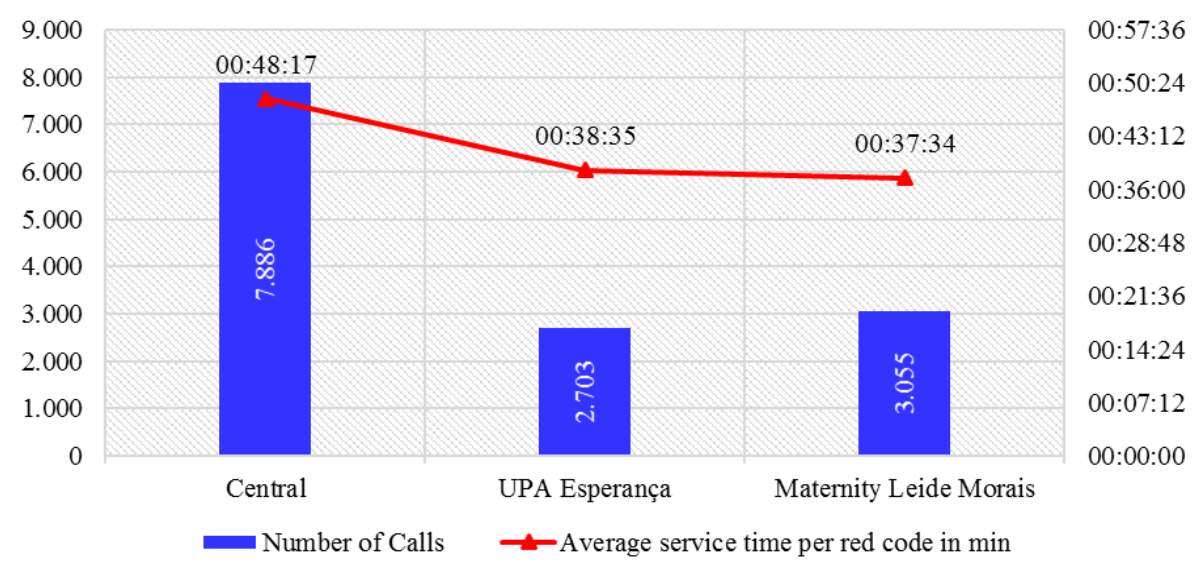

Source: the authors.

It can be seen from Figure 4 that the average response time of calls classified as red code from the Central base is 48 minutes, with a total of 7,886 calls answered. For the base installed in the neighborhood of the Cidade da Esperança, the average response time was 38 minutes with the attendance of 2,703 calls. The base located in the maternity Leide Moraes in the neighborhood of Nossa Senhora da Apresentação, had the average response time of 37 minutes with a total of 3,055 calls.

A survey of the average response time for care that resulted in the patient's death (5) reflects the current situation of the Natal emergency medical service. The deaths of users of this emergency medical service occur in three basic situations: in the transport vehicle (car) to the hospital (TVH), in the home of patient care and on public roads. 
Figure 5 - Number of deaths and average service time (min) of SAMU Natal / RN

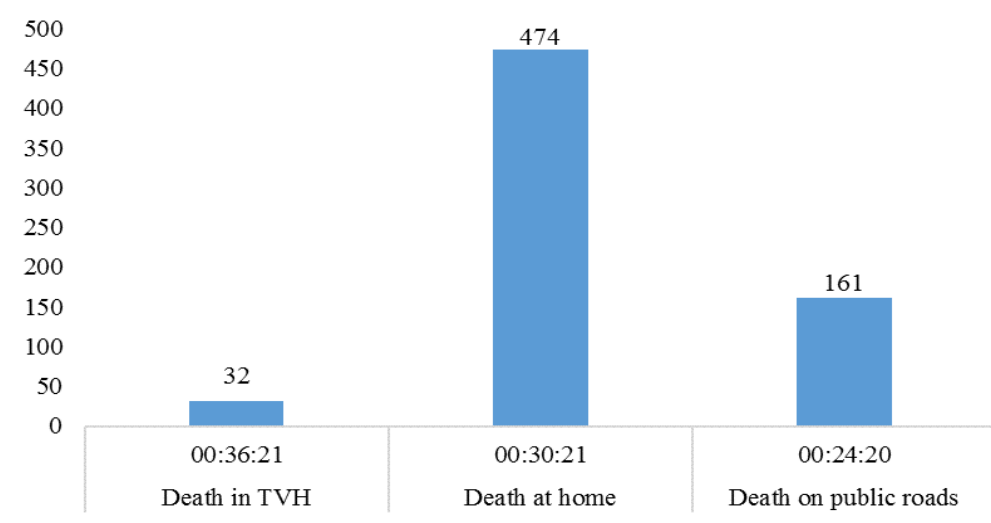

Source: the authors.

The average response time of calls that resulted in death in the car was over 36 minutes, with a total of 32 deaths in 2015. The average response time of calls that resulted in the patient's death at home was over 30 minutes and totaled 474 deaths. Finally, the average response time of calls that resulted in death on public roads was over 24 minutes, resulting in 161 deaths in 2015. These circumstances contrast with the reality of the referral emergency medical services cited in this article: many of which do not exceed 12 minutes of care.

Based on the situation described, a mathematical model is proposed that will contribute to the definition of the positioning of the provisional support bases of SAMU Natal so that the average response time identified in the figure analyzes explained above can be decreased. This model follows the Operational Research guidelines.

$\operatorname{Min} Z=\sum_{i} \Sigma_{j} h_{i} d_{i j} Y_{i j}$

Restrições:

$\sum_{j} X_{j}=P$

$\sum_{j} Y_{i j}=1 \forall i$

$Y_{i j}-X_{j} \leq 0 \forall i, j$

$X_{j} \in\{0,1\} \forall j$

$Y_{i j} \in\{0,1\} \forall i, j$

Where: 
$i=$ Neighborhood where care is required;

$j=$ Neighborhood where SAMU base is located;

$h_{i}=$ Neighborhood demand $\mathrm{i}$;

$d_{i j}=$ Distance between neighborhood $\mathrm{i}$ (location of care request) and neighborhood $\mathrm{j}$ (base location);

$P=$ Number of neighborhoods with SAMU base;

$X_{j} \in \mathbb{B}(1$ if the base is installed in vicinity $j$ and 0 , otherwise);

$Y_{i j} \in \mathbb{B}$ ( 1 if neighborhood $i$ will be served by the base located at $j$ and 0 otherwise);

For the creation of this model we used the parameters (inputs): number of calls from each neighborhood (neighborhood demand); distance from the base facility neighborhood to the required location (accident); the population of each neighborhood and the number of provisional support bases to be opened. While constraints on minimizing the average response time by setting interim support bases are: all demand will be allocated at least on an open basis (2); limitation of the number of bases to be implemented according to the convenience of each municipality (3) and permission to allocate demand (called) only to open or existing bases (4). The mathematical model is as follows:

The model was inserted and compiled in the AIMMS optimization program and scenarios were simulated in the model considering the installation of 3 to 8 bases. These scenarios were compared with the actual base location situation in 2015 (Figure 6). 
Figure 6 - Comparison of ambulance distances traveled from SAMU Natal / RN

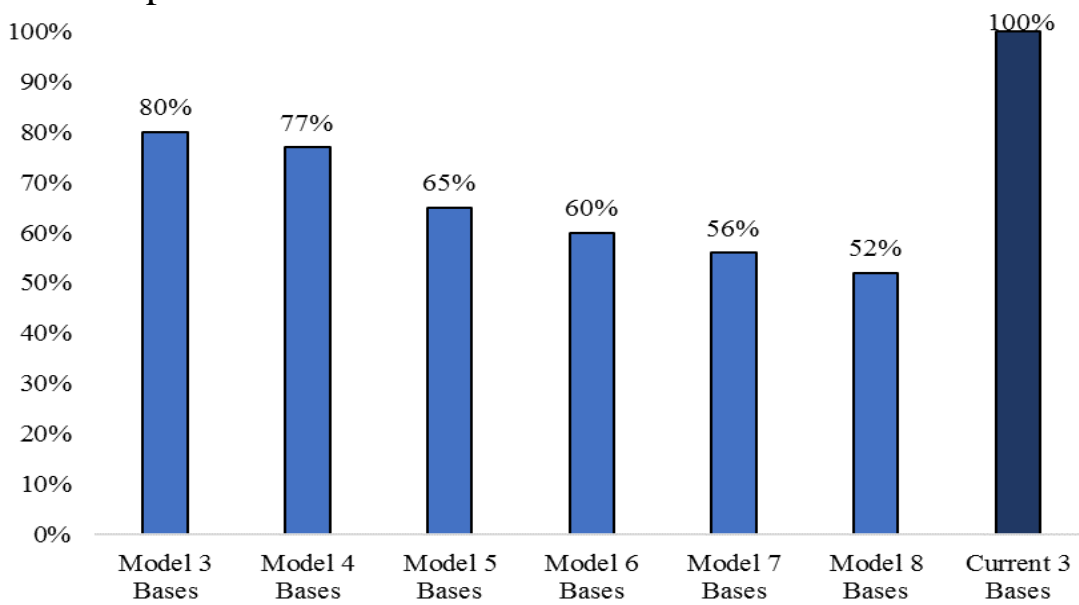

Source: The authors.

In Figure 6, the situation of SAMU bases in 2015 was considered as $100 \%$. This configuration reflects the actual distribution of SAMU bases in the city in 2015, in which the neighborhoods based were: Dix-Sept Rosado, Cidade da Esperança and Nossa Senhora da Apresentação. In this situation to meet the average number of calls per month, ambulances would cover 13,547 Km / month.

Considering the three base model, there is an optimization in the location of these bases resulting in a saving of $20 \%$ of the total distance traveled by ambulances when compared to the current situation., therefore, 2,773 kilometers less traveled by SAMU ambulances in one month.

Considering the four base model, there is a better optimization in the base location resulting in a $23 \%$ reduction in the total distance traveled by ambulances even when compared to the current situation.

There is a linear reduction when new bases are added to the developed model. This reduction in the distance traveled by ambulances can reach $48 \%$ when it is considered a scenario in the model with 8 open bases.

This reduction in the total distance traveled by ambulances, shown in Figure 7, results in a larger number of ambulances available to serve the population and directly reflects the reduction in the average response time of care, as ambulances will be closer to the required points. 
Figure 7 - Total distance traveled by ambulances by base (Km / month)

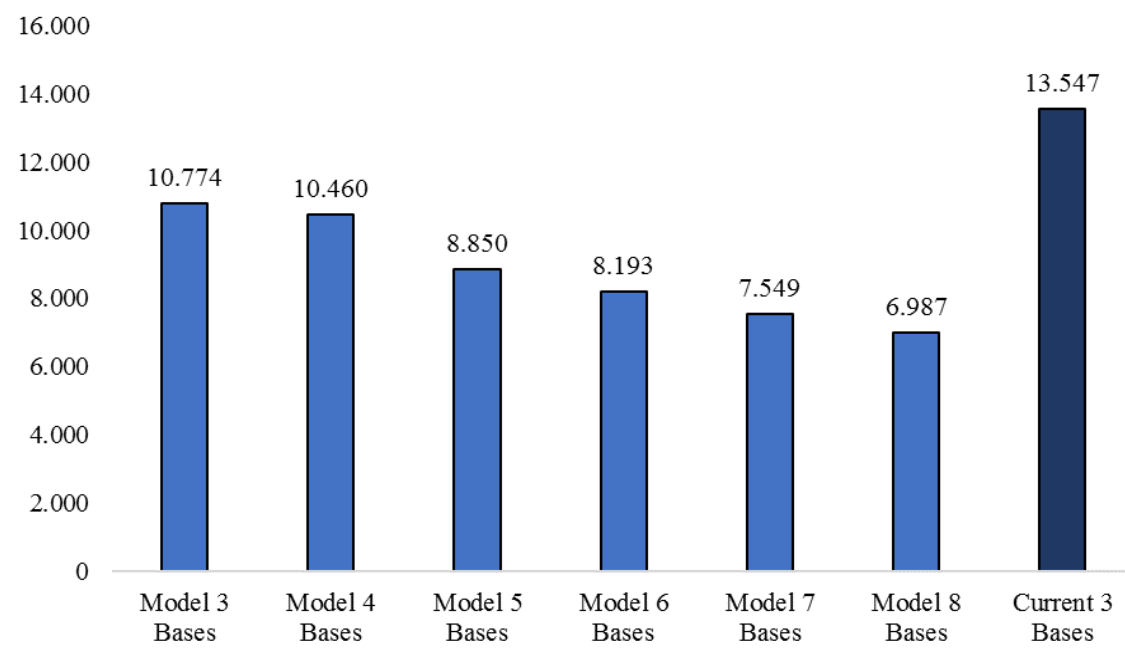

Source: The authors.

In accordance with guidance from SAMU/Natal's medical regulation coordinator, it signaled that the plan is to operate with 7 fixed bases in the municipality. Thus, this study demonstrated possible optimal points for the installation of these bases. Figure 1 illustrates the candidate neighborhoods as to the designation of a SAMU base, according to the mathematical model adopted in this study.

Figure 8 shows that the North Zone, which is one of the most populous of the municipality, will have 2 fixed bases installed in neighborhoods 02 and 04 (Potengi and Nossa Senhora da Apresentação), and this last neighborhood is currently covered by a base that is located internally Leide Moraes Maternity.

Although two bases suggested by the model developed for the North Zone, another base installed in neighborhood 11 (Praia do Meio) will also serve this Zone, bringing savings in the distance traveled by ambulances.

The model suggested the installation of two bases in the West Zone, another wellpopulated Zone. Base 23 (Bom Pastor) is located very close to neighborhood 22 (Dix Sept Rosado) and thus the installation of a new base can be saved with a slight adjustment to the model. The neighborhood 35 (Capim Macio) that serving the South Zone, proved more appropriate in the model, so almost in its entirety, the South Zone would be served by this base. 
Figure 8 - Neighborhoods that minimize the distance traveled in the model with 7 fixed bases
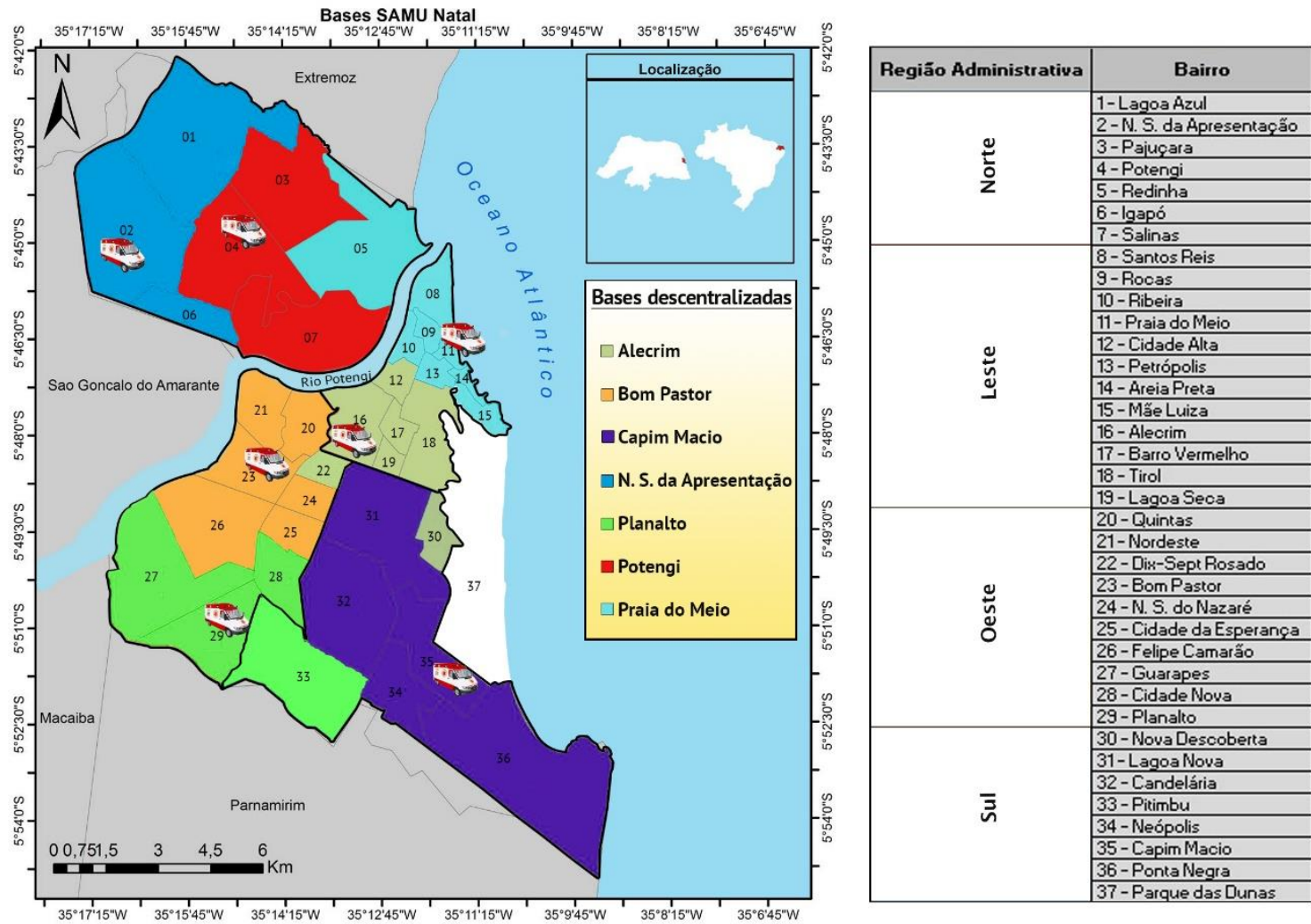

Source: The authors.

The developed model demonstrated the possibility of installing a base in neighborhood 16 (Alecrim). This neighborhood is a large trading center and has many calls throughout the day, but it is centrally located in the municipality and will be strategic to support other bases in times of high demand for services, as well as serving the entire East Zone.

\section{CONCLUSION}

The proposed model for service optimization was based on the total distance of ambulance displacement considering the number of calls. The model aimed to reduce the distance traveled by ambulances with the opening of new bases in neighborhoods of the city. These locations of the opening of the bases were the key points of the model. It was found in the model with the creation of several scenarios that adding new bases in an optimal location in the city had repercussions in reducing the distance traveled by ambulances, so as to increase call availability and reduce average call response time. 
It was found that when considering 7 optimally distributed bases in the city, there will be a $44 \%$ reduction in ambulance displacement, reflecting improved service and reduced average response time.

After presenting the scenarios to the SAMU team, new bases are being opened in the neighborhoods proposed by the model, but aiming at cost reduction and understanding that demand for demand of calls may vary over the years, these bases are being installed in dormitory containers, which have a low installation cost and may be relocated at future times.

The model does not allow quantifying how much reduction will occur in ambulance response time that is currently averaging over 40 minutes, as some important considerations such as traffic and hospital location were not considered. However, it can be said that with the reduction of ambulance displacements will positively reflect the response time of SAMU.

A new project is under development for the installation of GPS in ambulances to improve the model and quantify the reduction in ambulance response time, resulting in significant improvements for the Natal population and can be replicated in other locations.

\section{References}

ARINGHIERI, R.; CARELLO, G.; MORALE, D. Supporting decision making to improve the performance of an Italian Emergency Medical Service. Annals of Operations Research, v. 236, n. 1, p. 131-148, 2016.

BAHRAMI, M. A. et al. Pre-Hospital Emergency Medical Services in Developing Countries: A Case Study about EMS Response Time in Yazd, Iran. Iranian Red Crescent Medical Journal, v. 13, n. 10, p. 735-738, 2011.

BROTCORNE, L.; LAPORTE, G.; SEMET, F. Ambulance location and relocation models. European Journal of Operational Research, v. 147, n. 3, p. 451-463, 2003.

CHURCH, R. L.; DAVIS, R. R. The fixed charge maximal covering location problem. Papers in Regional Science, v. 71, n. 3, p. 199-215, 1992.

COSTA, L. P. DA; MORAIS, I. R. D. Espaço, iniquidade e transporte público: avaliação da acessibilidade urbana na cidade de Natal/RN por meio de indicadores de sustentabilidade. Sociedade \& Natureza, v. 26, n. 2, p. 237-251, 2014.

CABRAL E.L.S. et al. Response Time in Emergency Medical. Systematic Review. Acta Cirúrgica Brasileira, v.33, p. 1111-1121,2018. 
DASKIN, M.; STERN, E. A Hierarchical Objective Set Covering Model for Emergency Medical Service Vehicle Deployment. Transportation Science, v. 15, n. May, 1981.

FRAZÃO, T.et al. Multicriteria decision analysis (MCDA) in health care: a systematic review of the main characteristics and methodological steps. BMC Medical Informatics and Decision Making, v. 1, p. 1-16, 2018.

GENDREAU, M.; LAPORTE, G.; SEMET, F. Solving an ambulance location model by tabu search. Location Science, v. 5, n. 2, p. 75-88, 1997.

HILLIER, F.; LIEBERMAN, G. Introdução a Pesquisa Operacional. 8. ed. Porto Alegre: McGraw-Hill, 2010.

IGNÁCIO, A. A. V.; FERREIRA FILHO, V. J. M. O uso de software de modelagem AIMMS na solução de problemas de programação matemática. Pesquisa Operacional, v. 24, n. 1987, p. 197-210, 2004.

KIM, S. H.; LEE, Y. H. Iterative optimization algorithm with parameter estimation for the ambulance location problem. Health Care Management Science, p. 1-21, 2015.

MALTA, D. C. et al. Lesões no trânsito e uso de equipamento de proteção na população brasileira, segundo estudo de base populacional. Ciência \& Saúde Coletiva, v. 21, n. 2, p. 399-410, 2016.

MESSIAS, K. L. M. et al. Qualidade da informação dos óbitos por causas externas em Fortaleza, Ceará, Brasil. Ciência \& Saúde Coletiva, v. 21, n. 4, p. 1255-1267, 2016.

MINISTÉRIO DA SAÚDE. Diretrizes para a implantação do Serviço de Atendimento Móvel de Urgência (SAMU 192). [s.l: s.n.]. Disponível em: <http://bvsms.saude.gov.br/bvs/saudelegis/gm/2012/prt1010_21_05_2012.html>.

NOGUEIRA JUNIOR, L. C. Um estudo para redução do tempo de resposta do SAMU de Belo Horizonte através da realocação das bases de operação. p. 75, 2011.

PAHO, O. P. A. H. Situación de salud en las américas: Indicadores Básicos 2009. p. 12, 2009.

REICHENHEIM, M. E. et al. Violence and injuries in Brazil: The effect, progress made, and challenges ahead. The Lancet, v. 377, n. 9781, p. 1962-1975, 2011.

SHARIAT-MOHAYMANY, A. et al. Linear upper-bound unavailability set covering models for locating ambulances: Application to Tehran rural roads. European Journal of Operational Research, v. 221, n. 1, p. 263-272, 2012.

SOUZA, R. M. DE et al. Análise da configuração de SAMU utilizando múltiplas alternativas de localização de ambulâncias. Gestão e Produção, v. 20, p. 287-302, 2013. 
TAKEDA, R. A.; WIDMER, J. A.; MORABITO, R. Analysis of ambulance decentralization in an urban emergency medical service using the hypercube queueing model. Computers and Operations Research, v. 34, p. 727-741, 2007.

WANKHADE, P. Performance measurement and the UK emergency ambulance service: Unintended consequences of the ambulance response time targets. International Journal of Public Sector Management, v. 24, n. 5, p. 384-402, 2011. 